\title{
Organ weights in rats with activity-stress ulcers
}

\author{
WILLIAM P.PARÉ \\ Veterans Administration Hospital, Perry Point, Maryland 21902
}

\begin{abstract}
Rats were housed in activity cages and fed $1 \mathrm{~h}$ daily. When these rats died, wet and dry weights were obtained for adrenals, spleen, liver, kidney, heart, stomach rumen, and stomach body. Most activity rats, as compared to food-yoke control and home-cage control rats, had lesions in the glandular stomach. Adrenal and heart weights suggested that activity rats had been subjected to some degree of stress. Characteristic starvation effects, such as rumenal lesions and edema of stomach tissue, were not observed in activity rats.
\end{abstract}

Glandular lesions occur in rats which are housed in running wheel activity cages and fed only $1 \mathrm{~h}$ each day (Paré, 1974, 1975; Vincent \& Paré, 1976). Rats which are exposed to this regimen will die within 3 to 10 days and reveal lesions in the glandular stomach when autopsied. Control rats which are housed in standard cages without activity wheels and are fed the same amount of food as the activity rats do not die and are ulcer free. Since starvation induces stomach lesions in the rat (Paré \& Temple, 1973; Peters, 1967; Pfeiffer, 1970 ), the possibility existed that the lesions observed in activity rats were the result of the restricted feeding schedule. However, in a later study (Paré, 1975), control rats consumed the same amount of food as activity rats, and these control rats did not develop lesions.

Prolonged fasting in the rat has a number of characteristic effects on various organ systems. Rumenal lesions (cardiac stomach) and edema are commonly observed as a result of starvation (Pfeiffer, Dembro, \& Muller, 1966). The water content of the stomach tissue increases as a function of starvation (Peters, 1967). Some organs, notably liver and spleen, lose weight at a faster rate than total body weight, whereas adrenal and stomach rumen show a relative increase in weight as fasting continues (Peters \& Boyd, 1966). The weight of some organs, such as the heart and kidney, decreases at the same rate as total body weight during starvation (Peters, 1967). These studies show that in addition to rumenal lesions, starvation has typical effects on different organ systems. In the present study, rats were exposed to the activity-stress procedure and various organs were subsequently weighed to determine if the characteristic starvation effects were present in these animals. The study was performed to determine the extent to which activity-stress animals resembled starved animals and to further assess the impact of restricted feeding on the development of the activity-stress ulcer.

\section{METHOD}

\section{Subjects}

This experiment used 90 male Sprague-Dawley rats

This paper was supported by Veterans Administration Project No. 641-6905-08.
(ARS/Sprague-Dawley, Madison, Wisconsin) weighing 187-209 g at the beginning of the study.

\section{Apparatus}

Cages were standard running wheel activity cages (Wahmann Manufacturing Co., Baltimore, Maryland). Each activity wheel was equipped with an adjoining cage measuring $25 \times 15 \times 13 \mathrm{~cm}$. A sliding door separated the cage from its adjoining wheel. Wheel revolutions were recorded for each cage by an Esterline-Angus strip-chart event recorder and by digital counters. Room temperature was controlled at $74-75^{\circ} \mathrm{F}$, and daylight conditions were artificially maintained between 6 a.m. and 6 p.m.

\section{Procedure}

Rats were equated on the basis of body weight into three groups: an activity group, a food control group, and a homecage control group. Activity animals were individually housed in activity cages. Food control and home-cage control rats were individually housed in standard single laboratory cages. The food control animals were located in the same room with the activity animals, whereas the home cage animals were situated in one of the laboratory's animal colony rooms which had temperature and lighting conditions similar to those in the activity wheel room. During a 5-day cage-habituation phase, all rats had continuous access to food (granular Purina Rat Chow) and water. The doors in the activity cages were closed, thereby preventing entry into the wheel portion of the activity cages. On Day 6 , food was withdrawn from activity rats at 9 a.m., and the doors leading to the activity wheel were opened, allowing access to the running wheel. On Day 7, food was withdrawn from food control rats. On the same day, activity rats were fed for $1 \mathrm{~h}$ between 9 a.m. and $10 \mathrm{a} . \mathrm{m}$. The amount of food consumed was measured. Food control rats were individually matched with an activity rat, and the amount of food consumed by the activity rat in 1 day was subsequently fed to its food control mate on the next day. The number of wheel revolutions was recorded daily for each activity rat. All rats were weighed daily. Home-cage control rats had continuous access to food during the experiment.

When an activity rat died, the stomach was removed immediately and inspected for ulcers. The number of ulcers was counted and extent of ulceration was determined by measuring the length and width of each ulcer. The stomach was then separated into two parts: the body and the rumen. These were weighed on a Torbal analytical balance (Model EA-IAP). At the same time that the stomach was removed, the adrenals, spleen, liver, kidney, and heart were also removed and wet weights were obtained from these organs. Organs were then placed in a drying oven at $150^{\circ} \mathrm{C}$ for $16 \mathrm{~h}$, and a subsequent dry weight was obtained. When an activity rat died, its food-yoke control mate and home-cage control mate were killed $24 \mathrm{~h}$ later, and the stomachs and other organs treated as described above. The study continued for 21 days. Animals still alive at this time were killed with ether, and wet and dry organ weights were obtained. Differences in organ weights between groups were evaluated by an 
analysis of variance design with a post hoc Tukey a test for group comparisons (Winer, 1962).

\section{RESULTS}

Practically all activity rats died and revealed lesions in the glandular stomach. Lesions were observed in only one food-yoke control rat, and all home-cage control animals were ulcer free. These data are summarized in Table 1.

When compared to their pre-experimental body weights, activity animals lost $37.0 \%$ of their body weights by the end of the experimental period, foodyoke control rats lost $28.9 \%$, and home-cage control rats gained $36.8 \%$ in body weight.

The absolute dry and wet weights for the various organs are presented in Table 2. In this table, the organ weights of the activity rats and food-yoke control rats are compared to the home-cage control rats, and differences from home-cage controls are expressed as percent change. For both activity rats and food-yoke control rats, adrenals showed the least change from home-cage controls, whereas the greatest loss of both wet and dry weights was shown for spleen and liver.

Table 1

Summary of Stomach Pathology for the Three Treatment Conditions

\begin{tabular}{|c|c|c|c|c|}
\hline \multirow[b]{2}{*}{ Treatment } & \multirow[b]{2}{*}{$\mathrm{N}$} & \multirow{2}{*}{$\begin{array}{r}\text { Rats } \\
\text { With } \\
\text { Ulcers }\end{array}$} & \multicolumn{2}{|c|}{ Mean } \\
\hline & & & $\begin{array}{l}\text { Ulcers } \\
\text { Per Rat }\end{array}$ & $\begin{array}{c}\text { Ulcer } \\
\text { Length* }\end{array}$ \\
\hline Activity & 30 & 26 & 14.2 & 43.94 \\
\hline Food Yoke & 30 & 1 & 3.7 & 9.42 \\
\hline Home Cage & 30 & 0 & 0 & 0 \\
\hline
\end{tabular}

Table 3

Mean Relative Organ Weights and the Percentage of Water in All Organs for the Three Treatment Conditions

\begin{tabular}{|c|c|c|c|c|c|c|}
\hline \multirow[b]{3}{*}{ Organs } & \multicolumn{6}{|c|}{ Treatment Conditions } \\
\hline & \multicolumn{2}{|c|}{ Activity } & \multicolumn{2}{|c|}{ Food Yoke } & \multicolumn{2}{|c|}{ Home Cage } \\
\hline & $\begin{array}{l}\% \text { Body } \\
\text { Weight* }\end{array}$ & $\begin{array}{c}\% \\
\text { Water } \dagger\end{array}$ & $\begin{array}{l}\% \text { Body } \\
\text { Weight }\end{array}$ & $\begin{array}{c}\% \\
\text { Water }\end{array}$ & $\begin{array}{l}\% \text { Body } \\
\text { Weight }\end{array}$ & $\begin{array}{c}\% \\
\text { Water }\end{array}$ \\
\hline Adrenal & .0347 & 73.8 & .0300 & 72.6 & .0169 & 70.5 \\
\hline Spleen & .1129 & 76.3 & .1549 & 76.7 & .2782 & 77.8 \\
\hline Liver & 2.7646 & 76.6 & 3.6916 & 75.2 & 5.0984 & 74.4 \\
\hline Kidney & 1.0092 & 79.2 & .9425 & 78.0 & .8746 & 77.3 \\
\hline Heart & .4433 & 75.1 & .4317 & 77.5 & .3781 & 78.6 \\
\hline \multicolumn{7}{|l|}{ Stomach } \\
\hline Rumen & .2254 & 78.3 & .2150 & 78.3 & .1551 & 76.5 \\
\hline Body & .4960 & 80.9 & .5261 & 80.8 & .3991 & 77.9 \\
\hline
\end{tabular}

*Measured as percent of autopsy body weight

tMeasured as percent wet weight

Relative organ weights for all three treatment groups are outlined in Table 3 . Relative weights are expressed by percent of body weight and the water level, or percent water for each organ. There was a significant difference between groups for the adrenals $(F=123.73$, $\mathrm{df}=2 / 86, \mathrm{p}<.001)$. The relative adrenal weight of activity rats was significantly greater as compared to food-yoke rats $(p<.01)$, and the adrenals of food-yoke rats were significantly larger than home-cage controls $(p<.01)$. Significant differences were observed for relative spleen weights $(F=170.01$, df $=2 / 87$, $\mathrm{p}<.001)$. The spleens of home-cage rats were larger than the spleens of food-yoke controls $(p<.01)$ and the food-yoke control rats had larger spleens than those of the activity rats $(\mathrm{p}<.01)$. Significant differences in liver weights between groups $(F=61.04, d f=2 / 87, p<.001)$ reflected the pattern observed with spleen weights, with

*Millimeters

Table 2

Mean ( \pm SE) Absolute Dry and Wet Organ Weights for All Three Treatment Conditions

\begin{tabular}{|c|c|c|c|c|c|}
\hline \multirow[b]{2}{*}{ Organ } & \multirow{2}{*}{$\frac{\text { Home Cage }}{\begin{array}{c}\text { Organ Weight } \\
\text { (Grams) }\end{array}}$} & \multicolumn{2}{|c|}{ Activity } & \multicolumn{2}{|c|}{ Food Yoke } \\
\hline & & $\begin{array}{l}\text { Organ Weight } \\
\text { (Grams) }\end{array}$ & $\begin{array}{c}\% \\
\text { Change* }\end{array}$ & $\begin{array}{l}\text { Organ Weight } \\
\text { (Grams) }\end{array}$ & $\begin{array}{c}\% \\
\text { Change* }\end{array}$ \\
\hline & \multicolumn{5}{|c|}{ Dry Weight } \\
\hline $\begin{array}{l}\text { Adrenal } \\
\text { Spleen } \\
\text { Kidney } \\
\text { Heart } \\
\text { Liver } \\
\text { Stomach Rumen } \\
\text { Stomach Body }\end{array}$ & $\begin{array}{r}.0124 \pm .0006 \\
.1614 \pm .0034 \\
.5210 \pm .0109 \\
.2118 \pm .0047 \\
3.79 \pm .1325 \\
.0942 \pm .0019 \\
.2313 \pm .0039\end{array}$ & $\begin{array}{l}.0109 \pm .0003 \\
.0330 \pm .0027 \\
.2513 \pm .0048 \\
.1192 \pm .0032 \\
.8135 \pm .0757 \\
.0591 \pm .0028 \\
.1161 \pm .0058\end{array}$ & $\begin{array}{l}-.12 \\
-.79 \\
-.52 \\
-.43 \\
-.78 \\
-.37 \\
-.49\end{array}$ & $\begin{array}{r}.0115 \pm .0003 \\
.0513 \pm .0028 \\
.2865 \pm .0051 \\
.1361 \pm .0035 \\
1.3143 \pm .0741 \\
.0658 \pm .0023 \\
.1423 \pm .0037\end{array}$ & $\begin{array}{l}-.07 \\
-.68 \\
-.45 \\
-.35 \\
-.65 \\
-.30 \\
-.38\end{array}$ \\
\hline Stomach Body & \multicolumn{5}{|c|}{ Wet Weight } \\
\hline $\begin{array}{l}\text { Adrenal } \\
\text { Spleen } \\
\text { Kidney } \\
\text { Heart } \\
\text { Liver } \\
\text { Stomach Rumen } \\
\text { Stomach Body } \\
\text { Body Weight }\end{array}$ & $\begin{array}{l}.0439 \pm .0011 \\
.7282 \pm .0155 \\
2.293 \pm .0418 \\
.9585 \pm .0298 \\
13.39 \pm .3313 \\
.4060 \pm .0089 \\
1.047 \pm .0182 \\
254.3 \pm 4.42\end{array}$ & $\begin{array}{l}.0417 \pm .0011 \\
.1410 \pm .0126 \\
1.208 \pm .0208 \\
.5354 \pm .0136 \\
3.445 \pm .3103 \\
.2758 \pm .0152 \\
.6008 \pm .0194 \\
120.8 \pm 2.64\end{array}$ & $\begin{array}{l}-.05 \\
-.81 \\
-.47 \\
-.44 \\
-.74 \\
-.32 \\
-.43 \\
-.52\end{array}$ & $\begin{array}{l}.0420 \pm .0003 \\
.2218 \pm .0127 \\
1.321 \pm .0189 \\
.6069 \pm .0159 \\
5.275 \pm .2891 \\
.3039 \pm .0116 \\
.7402 \pm .0164 \\
140.7 \pm 2.40\end{array}$ & $\begin{array}{l}-.04 \\
-.69 \\
-.42 \\
-.36 \\
-.61 \\
-.25 \\
-.29 \\
-.45\end{array}$ \\
\hline
\end{tabular}

*Percent difference when compared to home-cage animals. 
home-cage animals having larger livers than food-yoke rats $(\mathrm{p}<.01)$ which, in turn, had larger livers than activity rats $(\mathrm{p}<.01)$. The significant differences in relative kidney weights $(F=25.30, d f=2 / 87, p<.001)$ were attributable to activity rats which had larger kidneys than food-yoke control rats $(p<.01)$ which, in turn, had larger kidneys than home-cage control rats $(\mathrm{p}<.01)$. Significant differences in relative heart weights $(F=19.92, \mathrm{df}=2 / 82, \mathrm{p}<.001)$ were attributable to significantly smaller weights of homecage animals as compared to the other two groups $(\mathrm{p}<.01)$. The difference in heart weights between activity rats and food control rats was not significant. Activity rats and food-yoke control rats did not differ with respect to the relative weight of the stomach rumen, but both groups had rumens larger than those of the home-cage animals $(\mathrm{p}<.01)$. The rumen water content of all three groups was essentially the same. The weight of the glandular stomach for food-yoke control animals was greater as compared to activity rats $(p<.01)$, and the weight of the glandular stomach of activity rats was heavier than that observed in home-cage control rats $(\mathrm{p}<.01)$.

\section{DISCUSSION}

Twenty-six activity rats and one food-yoke control rat had lesions in the glandular stomach. Rumenal lesions were not observed. These results are consistent with previous studies on the activity-stress ulcer (Paré, 1974, 1975; Vincent \& Paré, 1976).

Adrenals were the most resistant to weight changes. Other investigators (Peters, 1967; Pfeiffer, Dembro, \& Muller, 1966) have attributed the increase in relative adrenal weight change to stress. If this supposition is valid, the activity rats in the present study were subjected to more stress as compared to the other two treatment groups.

The organs which lost weight at approximately the same rate as the total body weight were kidney and heart. Jackson (1915) and Peters (1967) reported similar results for the kidney, and Beznàk (1954) and Peters (1967) reported similar results for the heart. The decrease in absolute heart weight may be due to a decrease in functional demand (Beznàk, 1954), but in the present study, activity rats had greater relative heart weights compared to the other groups. These results agree with Peters and Boyd (1968) who observed that the relative heart weight increased in rats subjected to starvation plus restraint stress.

The degree of weight loss was greater in spleen and liver as compared to total body weight loss. Peters and Boyd (1966, 1968) have reported similar results for the spleen. Other investigators (Leon, Feller, Neville, \& Daligcon, 1965; Nomura, 1965) suggested that liver weight decreases less in stressed rats as compared to starved rats because stress stimulates hepatic enzyme formation. This type of relationship was not observed in this study since the relative liver weight of activity rats was less than that observed in food-yoked control rats.

In the starved rat, the degree of stomach weight loss is less than total body weight, and this lower rate of weight loss is due to an increase in water in stomach tissue. Crater-like lesions in the cardiac stomach are also characteristic of starvation. In the present study, lesions were not observed in the rumen of the stomach, and a relative enlargement of the stomach was absent in activity rats. The characteristic starvation features of the stomach were absent in activity rats in this study.

The adrenal and heart data suggest that activity rats were subjected to a certain degree of stress. The stomach lesions resemble the stress ulcers reported by other investigators (Brodie, 1971) and are not the type characteristically produced by starvation. The spleen, liver, and kidney data do resemble typical changes brought about by starvation, and it would be unreasonable to conclude that reduced feeding has no input in the development of the activity-stress ulcer. However, on the basis of previous studies (Paré, 1974, 1975; Vincent \& Paré, 1976; Paré \& Houser, 1973) and the present study, it is reasonable to suggest that the activity-stress ulcer is not a starvation ulcer.

\section{REFERENCES}

BEzNÁ, M. The behavior of the weight of the heart and the blood pressure of albino rats under different conditions. Journal of Physiology, 1954, 124, 44-63.

Brodie, D. A. Stress ulcer as an experimental model of peptic ulcer disease. In C. J. Pfeiffer (Ed.) Peptic ulcer. Philadelphia: J. B. Lippincott, 1971. Pp. 71-83.

JACKSON, C. M. Effects of acute and chronic inanition upon the relative weights of the various organs and systems. American Journal of Anatomy, 1915, 18, 75-111.

Leon, H. A., Feller, O. D., Neville, E. D., \& Daligcon, B. Stress induced stimulation of liver protein synthesis indepen. dent of adrenal or pituitary action. Life Sciences, 1965, 4, 737-742.

NomURA, J. Effect of stress and psychotropic drugs on rat liver tryptophan pyrrolase. Endocrinology, 1965, 76, 1190.

PARÉ, W. P. Feeding environment and the activity-stress ulcer. Bulletin of the Psychonomic Society, 1974, 4, 546-548.

PARÉ, W. P. The influence of food consumption and running activity on the activity-stress ulcer in the rat. American Journal of Digestive Diseases, 1975, 20, 262-273.

Paré, W. P., \& Houser, V. P. Activity and food-restriction effects on gastric glandular lesions in the rat: The activitystress ulcer. Bulletin of the Psychonomic Society, 1973, 2 , 213-214.

Paré, W. P., \& Temple, L. J. Food deprivation, shock stress and stomach lesions in the rat. Physiology and Behavior, 1973, 11, 371-375.

Peters, J. M. Effects of absolute starvation and refeeding on organ weights and water contents of albino rats. Growth, 1967, 31, 191-203.

Peters, J. M., \& Boyd, E. M. Organ weights and water levels of the rat following reduced food intake. Journal of Clinical Nutrition, 1966, 90, 354-360.

PETers, J. M., \& BoYD, E. M. Organ weights and water contents during acute starvàtion, thirst and stress. Growth, 1968, 32, 283-286.

Pfeiffer, C. J. Gastrointestinal response to malnutrition and starvation. Postgraduate Medicine, 1970, 47, 110-115.

Pfeiffer, C. J., Dembro, F. R., \& Muller, P. J. Gastric pathologic and biochemical changes induced by starvation of weanling rats. Life Sciences, 1966, 5, 509-519.

Vincent, G. P., \& PARÉ, W. P. Activity-stress ulcer in the rat, hamster, gerbil and guinea pig. Physiology and Behavior, 1976, 16, 557-560.

WINER, B. J. Statistical principles in experimental design. New York: McGraw-Hill, 1962.

(Received for publication August 10, 1976.) 